(c) American Dairy Science Association, 2006.

\title{
Leptin Does Not Act Directly on Mammary Epithelial Cells in Prepubertal Dairy Heifers
}

\author{
S. R. Thorn, ${ }^{\star 1}$ S. Purup,$\dagger^{1}$ W. S. Cohick, $\neq M$ M. Vestergaard, $\dagger$ K. Sejrsen, $†$ and Y. R. Boisclair ${ }^{\star 2}$ \\ *Department of Animal Science, Cornell University, Ithaca, NY14853 \\ †Department of Animal Health, Welfare and Nutrition, Danish Institute of Agricultural Sciences, DK-8830, Tjele, Denmark \\ $\ddagger$ Department of Animal Sciences, Rutgers, The State University of New Jersey, New Brunswick 08901
}

\section{ABSTRACT}

The mammary gland of prepubertal dairy heifers consists of parenchyma expanding into the stroma, a matrix of connective and adipose tissue. High planes of nutrition increase stromal mass, but inhibit growth of parenchyma. The parenchyma consists of epithelial cells proliferating in response to growth factors such as insulin like growth factor-I (IGF-I). These observations have led to the hypothesis that elevated planes of nutrition increase leptin production, which in turn inhibits IGF-I-mediated epithelial cell proliferation. To assess this possibility, heifers were offered planes of nutrition sustaining average daily gains of $715 \mathrm{~g} / \mathrm{d}$ (normal; NP) or 1,202 g/d (high; HP) from $42 \mathrm{~d}$ of age until slaughter at $240 \mathrm{~kg}$. At slaughter, HP heifers had 2-fold greater plasma leptin concentration and 3 -fold greater leptin mRNA abundance in mammary stroma and parenchyma. To assess the causal nature between leptin and parenchymal development, the induction of signaling events and functional responses in the MAC-T cell line and in primary mammary epithelial cells by leptin was examined. Leptin did not induce phosphorylation of signal transducers and activators of transcription (STAT)3, STAT5, extracellular signal-regulated kinase (ERK1/2), or AKT/Protein kinase B. Consistent with its inability to signal, leptin did not alter basal- or IGF-I-stimulated thymidine incorporation or increase suppressors of cytokine signaling 3 (SOCS3) expression in these cells. Transcripts corresponding to the short leptin receptor form were present in mammary tissue, but those corresponding to the long signaling form were not detected in either mammary tissue or cells. In conclusion, elevated planes of nutrition increase leptin synthesis in mammary stroma, but leptin does not act directly on bovine mammary epithelial cells.

Received September 17, 2005

Accepted November 21, 2005.

${ }^{1}$ S. R. Thorn and S. Purup contributed equally to this work.

${ }^{2}$ Corresponding author: yrb1@cornell.edu
Key words: leptin, mammary gland development, cattle, nutrition

\section{INTRODUCTION}

In prepubertal dairy heifers, planes of nutrition sustaining average daily gains (ADG) in excess of 700 g/d have been associated with decreased mammary parenchymal growth (Sejrsen et al., 1982, 2000; Capuco et al., 1995). The mechanisms whereby elevated planes of nutrition cause this effect remain undefined. Research initially focused on hormones that drive prepubertal mammary development (Purup et al., 1993; Radcliff et al., 1997; Sejrsen et al., 1999), but more recent evidence indicates that mammary-derived factors may be more important (Akers et al., 2000; Purup et al., 2000a,b). Specifically, when mammary epithelial cell proliferation is used as a bioassay, mammary parenchymal extracts obtained from rapidly growing heifers are less potent than those obtained from normal-growing heifers, whereas the opposite result is observed with serum (Purup et al., 2000b; Weber et al., 2000a). Mammary extracts from rapidly growing heifers have increased abundance of IGF-I binding protein 3, indicating that an attenuation of IGF-Imediated epithelial cell proliferation may account for their decreased potency (Weber et al., 2000b; Berry et al., 2001).

During prepubertal development, the parenchyma expands into the stroma, a matrix of connective and adipose tissue (Hovey et al., 1999). Rodent studies have shown that epithelial cell growth proceeds normally only in the presence of adipose tissue, reflecting the importance of production of growth factors such as IGF-I by this tissue compartment (Kleinberg et al., 2000; Couldrey et al., 2002; Richards et al., 2004). Elevated planes of nutrition increase mammary stromal mass disproportionately (Sejrsen et al., 1982; Capuco et al., 1995; Radcliff et al., 1997), raising the possibility that they stimulate the synthesis of an adipose-derived factor that inhibits epithelial cell growth. This hypothesis has been bolstered recently by the reports that leptin reduces IGF-I-mediated prolifera- 
tion of a bovine mammary epithelial cell line (Silva et al., 2002) and that leptin infusion into the bovine mammary gland reduces IGF-I-mediated proliferation (Silva et al., 2003). Leptin, however, acts primarily on hypothalamic neurons and whether mammary epithelial cells can be added to the limited number of peripheral cells capable of responding to leptin is not known at this time (Ahima and Flier, 2000; Bjorbaek and Kahn, 2004; Myers, 2004).

In the present study, 2 conditions have been examined that must be fulfilled for leptin to represent a physiological factor that directly regulates mammary epithelial cell growth. First, it was assessed whether leptin synthesis by mammary stroma is increased in rapidly growing prepubertal heifers experiencing decreased mammary parenchymal growth. The second condition assessed was whether leptin can induce early signaling events and functional responses in mammary epithelial cells. Our results indicate that mammary leptin synthesis is increased in rapidly growing heifers, but that leptin does not act directly on mammary epithelial cells.

\section{MATERIALS AND METHODS}

\section{Prepubertal Heifer Experiment}

All experimental procedures complied with Danish laws and regulations for the humane care and use of heifers in research [The Danish Ministry of Justice, Animal Testing Act (Consolidation Act No. 726 of September 9, 1993 as amended by Act No. 1081 of December 20, 1995)]. Furthermore, the Danish Animal Experimentation Inspectorate approved the study protocols and supervised the experiment. Heifers were housed in individual stalls under ambient light and temperature. The experiment was repeated in 2 consecutive years with 12 heifers per year. HolsteinFriesian heifer calves received colostrum from birth until $4 \mathrm{~d}$ of age. Between 5 and $42 \mathrm{~d}$ of age, they were fed whole milk at rates sustaining an ADG of $889 \pm$ $28 \mathrm{~g} / \mathrm{d}$. They were then randomly allocated to a normal (NP) or high (HP) plane of nutrition (12 heifers per treatment) until slaughter at $240 \mathrm{~kg}$. The NP heifers were offered ad libitum amounts of a forage-based TMR (57\% barley straw, 43\% concentrate; 8.4 MJ of $\mathrm{ME}$, and $116 \mathrm{~g}$ of $\mathrm{CP} / \mathrm{kg}$ of $\mathrm{DM})$. The HP heifers were allowed free access to a concentrate ration (12.7 MJ of ME and $228 \mathrm{~g}$ of $\mathrm{CP} / \mathrm{kg}$ of $\mathrm{DM}$ ) supplemented with the forage-based TMR (1.0 to $1.5 \mathrm{~kg} / \mathrm{d}$ ).

Body weights were recorded on 2 consecutive days around $42 \mathrm{~d}$ of age and immediately before slaughter. Blood samples were obtained weekly during the last 3 wk before slaughter. Sampling was performed $2 \mathrm{~h}$ after the morning feeding by jugular venipucture.
Plasma was prepared and analyzed for leptin, IGF-I, and insulin using previously validated immunoassays (Frystyk et al., 1995; Ehrhardt et al., 2000; Lovendahl and Purup, 2002). Heifers were declared pubertal when their progesterone concentration (Human CoatA-Count RIA kit, Diagnostic Products Corporation, Scandinavia, Denmark) exceeded $1 \mathrm{ng} / \mathrm{mL}$ in 2 consecutive samples. At slaughter, the mammary gland was removed and skinned. The udder was separated into right and left halves at the medial suspensory ligament. The skinned left half was used to collect parenchymal and stromal tissue for RNA extraction. These samples were immediately frozen in liquid nitrogen. The right half of the udder was frozen at $-80^{\circ} \mathrm{C}$ until quantitative measurement of tissue composition (Sejrsen et al., 1986). Parenchyma DM was determined by drying at $80^{\circ} \mathrm{C}$ to a constant weight. Fat content was assayed by ether extraction. Dry fat-free tissue was calculated as DM minus fat content.

\section{Bovine Mammary Epithelial Cells}

The MAC-T bovine mammary epithelial cell line was established from primary bovine mammary alveolar cells by immortalization with the SV-40 large T antigen (Huynh et al., 1991). The MAC-T cells were routinely grown at $37^{\circ} \mathrm{C}$ with $5 \% \mathrm{CO}_{2}$ in basal Dulbecco's modified Eagle's medium (DMEM, with $4.5 \mathrm{M}$ glucose containing $20 \mathrm{U} / \mathrm{mL}$ of penicillin, and $2.4 \mathrm{n} M$ glutamine) supplemented with $10 \%$ fetal calf serum and 5 $\mu \mathrm{g} / \mathrm{mL}$ of insulin. Mammary epithelial cell organoids were obtained from 2 independent isolations by digestion of the parenchymal mammary compartment of prepubertal Friesian heifers as described previously (Purup et al., 2001). Frozen stocks of these primary mammary epithelial cells (pMEC) were thawed as needed in basal medium 199 (M199 containing $2.6 \mathrm{~g} /$ $\mathrm{L}$ of BSA, $5 \mathrm{mg} / \mathrm{L}$ of transferrin, $1 \mathrm{mg} / \mathrm{L}$ of reduced glutathione, $1 \mathrm{mg} / \mathrm{L}$ of soybean trypsin inhibitor, 1 $\mu \mathrm{g} / \mathrm{L}$ of selenium, $0.2 \%$ of penicillin and streptomycin antibiotic solution), and kept at $37^{\circ} \mathrm{C}$ with $5 \% \mathrm{CO}_{2}$.

Recombinant proteins used included ovine leptin (ProSpec-Tany TechnoGene Ltd., Israel), human leptin (National Institute of Diabetes, and Digestive and Kidney Diseases, NIDDK, Bethesda, MA), human transforming growth factor-alpha (R\&D Systems, Minneapolis, MN), human IL-6 (PeproTech Ltd., Rocky Hill, NJ), human IGF-I (NIDDK for MAC-T; Austral Biologicals, Aarhus, Denmark for pMEC), and bovine IFN $\gamma$ (Dale Godson, Veterinary Infectious Disease Organization, Saskatoon, SK, Canada). 


\section{Intracellular Signaling and Western Immunoblotting}

The MAC-T cells were plated at $5.0 \times 10^{3}$ cells $/ \mathrm{cm}^{2}$ in 6 -well plates and grown to 80 to $90 \%$ confluence. Cells were washed twice with PBS ( $137 \mathrm{mM} \mathrm{NaCl}, 2.7$ $\mathrm{m} M \mathrm{KCl}, 1.4 \mathrm{n} M \mathrm{KH}_{2} \mathrm{PO}_{4}, 4.3 \mathrm{~m} M \mathrm{Na}_{2} \mathrm{HPO}_{4}$ ), and incubated in basal DMEM for $30 \mathrm{~h}$ with a media change after $24 \mathrm{~h}$. Experiments were initiated by the addition of hormones to the existing basal DMEM to achieve the final concentration. At the times given in the figure legend (Figure 2), cells were washed twice with icecold PBS containing $0.4 \mathrm{mM}$ sodium orthovanadate. Cells were ruptured with $80 \mu \mathrm{L}$ of lysis buffer $(10 \mathrm{mM}$ Tris, $1.0 \%$ Triton X-100, $150 \mathrm{~m} M \mathrm{NaCl}, 1 \mathrm{~m} M$ ethylene glycoltetraacetic acid, $1 \mathrm{~m} M$ sodium orthovanadate, 1 $\mathrm{m} M$ sodium pyrophosphate, $10 \mathrm{~m} M$ sodium fluoride, $10 \mu \mathrm{g} / \mathrm{mL}$ aprotinin, $10 \mu \mathrm{g} / \mathrm{mL}$ leupeptin, and $1 \mathrm{~m} M$ phenylmethylsulfonyl fluoride). Lysates were collected, incubated on ice for $15 \mathrm{~min}$, and cleared by centrifugation. The pMEC were thawed in basal M199 medium, plated in 24-well plates (400 $\mu \mathrm{g}$ of protein/ well), and experiments were initiated after $4 \mathrm{~h}$ by the addition of hormones as indicated in the figure legend (Figure 3). At the given times, cells were transferred to ice-cold tubes and washed twice with ice-cold PBS containing $0.4 \mathrm{~m} M$ sodium orthovanadate. Cells were recovered by centrifugation and lysates were prepared as described for MAC-T cells.

Protein concentrations of cell lysates were determined using the bicinchoninic acid (BCA) assay (Pierce, Rockford, IL). Proteins were separated on 10\% SDS polyacrylamide gels and transferred onto nitrocellulose membranes (Protran, Schleicher and Schuell, Keene, NH; Hybond C membranes, Amersham Biosciences, Hillerød, Denmark). Membranes were incubated for $1 \mathrm{~h}$ in blocking solution (50 $\mathrm{mM}$ Tris, $\mathrm{pH}$ 7.4, $200 \mathrm{~m} M \mathrm{NaCl}, 0.1 \%$ Tween 20, 5\% NDM). Membranes were incubated with primary antibodies specific for signal transducers and activators of transcription (STAT)3 phosphorylated on tyrosine 705 (pY $^{705}$ STAT3; Cell Signaling, Beverly, MA), STAT5 phosphorylated on tyrosine 694 (pY ${ }^{694}$ STAT5; Cell Signaling), Akt/protein kinase B (AKT) phosphorylated on serine 473 ( $\mathrm{pS}^{473} \mathrm{AKT}$; Cell Signaling), extracellular signal-regulated kinase (ERK)1/2 phosphorylated on tyrosine 204 (pY ${ }^{204}$ ERK1/2; Santa Cruz, Santa Cruz, CA), total STAT3 (Santa Cruz), total STAT5 (Santa Cruz), total AKT (Cell Signaling), and total ERK1/ 2 (Upstate, Lake Placid, NY). Antibody dilution and incubation conditions were as recommended by the manufacturers. After incubation, membranes were washed followed by incubation with horseradish peroxidase-linked secondary antibody for $1 \mathrm{~h}$ (KPL, Gaith- ersburg, MD; Santa Cruz). The signals were detected with LumiGlo chemiluminescence reagents (KPL) and autoradiography.

\section{Cell Proliferation Assays}

The MAC-T cells were plated at $1 \times 10^{4}$ cells $/ \mathrm{cm}^{2}$ into 48-well plates and cultured for $48 \mathrm{~h}$. Cells were washed twice with PBS and incubated in basal DMEM for $24 \mathrm{~h}$. After $24 \mathrm{~h}$, the media was changed to basal DMEM supplemented with [methyl- ${ }^{3} \mathrm{H}$ ] thymidine (1 $\mu \mathrm{Ci} /$ well; MP Biomedicals, Irvine, CA) and hormones for $18 \mathrm{~h}$ as indicated in figure legend (Figure 4). In the case of pMEC, the 2 independent cell isolates were mixed 1:1, and seeded in basal M199 supplemented with $10 \mu \mathrm{g} / \mathrm{L}$ of insulin (Sigma, St. Louis, MO) into 3dimensional gels as described previously (Weber et al., 1999). After $24 \mathrm{~h}$, cells were incubated for $4 \mathrm{~d}$ with basal M199 supplemented with insulin and indicated hormones (see figure legends). Media were changed every $2 \mathrm{~d}$ and $\left[{ }^{3} \mathrm{H}\right]$ thymidine was added for the last $24 \mathrm{~h}$ of the culture period. For both cell systems, all treatments were performed in triplicate. Thymidine incorporation was measured as previously reported for MAC-T (Grill and Cohick, 2000) and pMEC (Weber et al., 1999).

\section{RNA Isolation and Analysis}

The guanidinium thiocyanate-phenol-chloroform method was used to extract RNA for Northern analysis (Chomczynski and Sacchi, 1987) and affinity chromatography (Qiazol and RNeasy Mini Kit, Qiagen, Valencia, CA) was used for ribonuclease protection assay and real-time PCR assays. The quality of RNA was assessed by RNA formaldehyde gel electrophoresis and the RNA 6000 Nano LabChip Kit (Agilent Technologies, Palo Alto, CA). Leptin and glyceraldehyde-3-phosphate dehydrogenase (GAPDH) mRNA transcripts were measured simultaneously by ribonuclease protection assay (Block et al., 2001). Suppressors of cytokine signaling (SOCS)3 mRNA was measured by Northern analysis with a 642-bp bovine SOCS3 cDNA probe (GenBank accession number NM_174466). Equality of loading was verified by $18 \mathrm{~S}$ rRNA hybridization (Deindl, 2001).

Quantitative real-time PCR assays were designed to measure transcripts corresponding to leptin, one of the short leptin receptor isoforms (Ob-Ra), the long leptin receptor isoform (Ob-Rb), and all leptin receptor isoforms $\left(\mathbf{O b}-\mathbf{R}_{\text {Total }}\right)$. Each assay relied on a probe spanning adjoining exons and was designed using Primer Express version 2.0 (Table 1; Applied Biosystems, Foster City, CA). Total RNA ( $2 \mu \mathrm{g})$ was reverse 
Table 1. Real-time PCR primer and probe sequences

\begin{tabular}{ll}
\hline Transcript & Sequence $^{1}$ \\
\hline Leptin & \\
Forward & TCACCAGGATCAATGACATCTCA \\
Reverse & ACCAGTGACCCTCTGTTTGGA \\
Probe & FAM-CACGCAGTCCGTCTC-MGB \\
Ob-Rb & \\
Forward & TCCTCCTCAATCTTATTGCTTGG \\
Reverse & TGCTTGATAAAAAGATGCTCAAATG \\
Probe & FAM-AGTGTCACATCAAAGAA-MGB \\
Ob-Ra & TCCTCCTCAATCTTATTGCTTGG \\
Forward & TCAAAGAATGTCCGTTCTCTTCTG \\
Reverse & FAM-AGTGTCACATCAAAGAA-MGB \\
Probe & \\
Ob-R & \\
Forward & GTGCTGGCCATCAATCAATT \\
Reverse & GGGTGACAGCATCCAGGAA \\
Probe & FAM-CAGCAAAGTAAATATCG-MGB \\
\hline
\end{tabular}

${ }^{1}$ For each transcript, the sequence of the forward primer, reverse primer, and probe are given in the $5^{\prime}$ to $3^{\prime}$ direction. FAM = carboxyfluorescein; MGB = minor groove binding dye; TAMRA = carboxytetramethylrhodamine; Ob-R = leptin receptor.

transcribed with SuperScript II (Invitrogen, Carlsbad, CA) as recommended by the supplier. Reverse-transcribed RNA (400 ng for Ob-Rb and $100 \mathrm{ng}$ for others) was amplified in a $25-\mu \mathrm{L}$ volume using $2 \times$ Universal Master Mix (Applied Biosystems). Reactions were performed on an ABI 7000 Thermocycler using standard thermocycling conditions (Applied Biosystems). Optimal primer and probe concentrations were achieved with $500 \mathrm{n} M$ of each primer and $100 \mathrm{n} M$ of probe. Standards were amplified in triplicate and unknowns were amplified in duplicate. The 18S Ribosomal Control Reagents (Applied Biosystems) were used to control for differences in starting template amounts. Expression was declared undetectable in samples with a cycle threshold $\left(\mathrm{C}_{\mathrm{T}}\right)$ greater than 37 based on inconsistent amplification beyond this cycle threshold (Bustin and Nolan, 2004).

For leptin, the comparative $\mathrm{C}_{\mathrm{T}} \operatorname{method}\left(\Delta \Delta \mathrm{C}_{\mathrm{T}}\right)$ method was used to determine relative expression because the leptin and $18 \mathrm{~S}$ reactions had equal efficiencies (User Bulletin \#2, Applied Biosystems). Leptin expression is reported as a fold difference relative to a pooled cDNA sample prepared from the stroma of NP heifers. For leptin receptor assays, relative standard curves were generated using serial 2-fold dilutions of cDNA prepared from a prepubertal heifer hypothalamus pool. Unknown sample expression was then determined from the standard curve and expressed as a fold difference relative to the hypothalamus pool (User Bulletin \#2, Applied Biosystems).

\section{Statistical Analyses}

Analyses were performed using SAS statistical software (SAS Institute, Inc., Cary, NC). Growth and
Table 2. Effect of the plane of nutrition on growth rate, mammary gland growth, and plasma hormones in prepubertal heifers

\begin{tabular}{|c|c|c|c|c|}
\hline \multirow[b]{2}{*}{ Variable } & \multicolumn{2}{|c|}{ Plane of nutrition ${ }^{1}$} & \multirow[b]{2}{*}{ SEM } & \multirow[b]{2}{*}{$P$-value ${ }^{2}$} \\
\hline & NP & $\mathrm{HP}$ & & \\
\hline \multicolumn{5}{|l|}{ Whole animal } \\
\hline Average daily gain, g/d & 715 & 1,202 & 34 & $<0.001$ \\
\hline Age at slaughter, $d$ & 257 & 194 & 4 & $<0.001$ \\
\hline \multicolumn{5}{|l|}{ Mammary mass, $\mathrm{g}^{3}$} \\
\hline Total gland & 920 & 1,992 & 126 & $<0.001$ \\
\hline Parenchyma & 446 & 243 & 43 & $<0.05$ \\
\hline Parenchyma DFFT ${ }^{4}$ & 44 & 23 & 5 & $<0.05$ \\
\hline Stroma & 474 & 1,749 & 124 & $<0.001$ \\
\hline \multicolumn{5}{|l|}{ Plasma concentration $^{5}$} \\
\hline Leptin, ng/mL & 1.4 & 2.9 & 0.2 & $<0.001$ \\
\hline Insulin, log $\mathrm{pmol} / \mathrm{L}$ & 3.8 & 5.1 & 0.1 & $<0.001$ \\
\hline IGF-I, ng/mL & 134 & 290 & 24 & $<0.001$ \\
\hline
\end{tabular}

${ }^{1}$ Dairy heifers were offered a normal (NP) or high (HP) plane of nutrition between $42 \mathrm{~d}$ of age and slaughter at $240 \mathrm{~kg}$.

${ }^{2}$ Type I error.

${ }^{3}$ Represents total mammary gland mass based on dissection and weights of half the gland.

${ }^{4}$ Dry fat-free tissue (DFFT) mass was determined in parenchymal samples.

${ }^{5}$ Analyses were performed on blood samples obtained weekly during the last $3 \mathrm{wk}$ before slaughter. In the case of insulin, the statistical analysis was performed on log-transformed data and means and SEM reported as log-transformed values.

plasma data from the in vivo experiment were analyzed using the GLM procedure and included BW at slaughter as a covariate and fixed effects of nutrition (NP vs. HP), year of experiment (block), and their interaction. Relative leptin mRNA abundance in prepubertal heifers was analyzed using the GLM procedure with nutritional treatment as the fixed effect. Correlation analyses were performed using the CORR procedure. Thymidine-incorporation data were analyzed with fixed effects of leptin, IGF-I, their interaction, and experiment (block). Leptin receptor real-time PCR data were analyzed with a MIXED model accounting for nutrition (NP vs. HP), mammary tissue compartment (stroma vs. parenchyma), and their interaction as fixed effects and heifer as the random effect.

\section{RESULTS}

\section{Inverse Relationship Between Mammary Parenchymal Mass and Leptin Production}

Mammary parenchymal growth is reduced when the ADG of prepubertal dairy heifers exceeds $700 \mathrm{~g} / \mathrm{d}$ (Sejrsen et al., 2000). To examine whether increased leptin production is associated with this effect, dairy heifers beginning at $42 \mathrm{~d}$ of age were fed planes of nutrition designed to sustain the recommended ADG of about $700 \mathrm{~g} / \mathrm{d}$ (NP) or greater ADG (HP). The HP heifers grew nearly twice as fast as the NP heifers and were younger when slaughtered at $240 \mathrm{~kg}$ (Table $2, P<$ 
A) Stroma

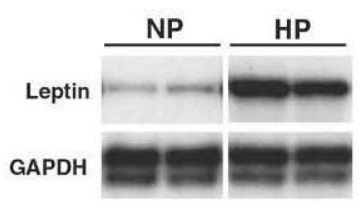

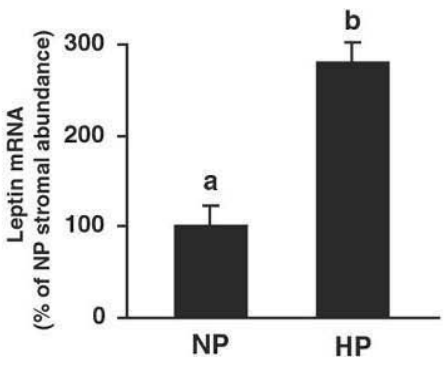

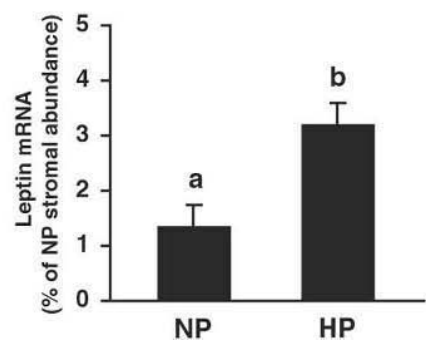

Figure 1. Effect of nutrition on leptin mRNA abundance in mammary stroma and parenchyma. Dairy heifers were offered a normal (NP) or high (HP) plane of nutrition between $42 \mathrm{~d}$ of age and slaughter at $240 \mathrm{~kg}$ (12 heifers per treatment). A) Left: Total RNA (3 $\mu \mathrm{g})$ was extracted from mammary stroma and analyzed simultaneously by ribonuclease protection assay for the abundance of leptin and glyceraldehyde-3-phosphate dehydrogenase (GAPDH) mRNA. Data shown are from 2 representative heifers at each plane of nutrition. Right: Leptin signals were quantified by phosphor imaging, adjusted relative to the GAPDH signal, and expressed as a percentage of leptin expression in stroma of NP heifers. Means \pm SEM are shown for each treatment. Bars with different letters differ $(P<0.001)$. B) Total RNA was extracted from mammary parenchyma and analyzed by real-time PCR for the abundance of leptin. Results are expressed as a percentage of leptin expression in stroma of NP heifers. Means \pm SEM are shown for each treatment. Bars with different letters differ $(P<0.001)$.

0.001). As expected, HP heifers had a $46 \%$ reduction $(P<0.05)$ in mammary parenchymal mass and a $48 \%$ reduction $(P<0.05)$ in dry fat-free tissue. This reduction was associated with a 3 -fold increase $(P<0.001)$ in stromal mass such that the mammary gland of HP heifers was twice as heavy $(P<0.001)$ as that of NP heifers. Only 2 heifers, both on the HP plane of nutrition, reached puberty by the time of slaughter.

Next, mammary and systemic indices of leptin production were measured. At slaughter, stromal leptin mRNA abundance was 3 -fold greater $(P<0.001)$ in HP than NP heifers (Figure 1A). A comparable effect of nutrition was observed when leptin mRNA was assayed in parenchyma (Figure $1 \mathrm{~B}, P<0.001$ ). Parenchymal leptin expression was small, reaching only 1 to $3 \%$ of the expression seen in the stroma of the NP heifers. Leptin mRNA could not be detected in mammary epithelial cells isolated from prepubertal heifers (pMEC) when assayed by quantitative real-time PCR.

Consistent with increased mammary leptin production, HP heifers had increased $(P<0.001)$ plasma leptin concentrations during the last $3 \mathrm{wk}$ of treatment (Table 2). Plasma leptin was positively correlated ( $P$ $<0.01$ ) with leptin mRNA abundance in the mammary stroma $(r=0.65)$ and parenchyma $(r=0.57)$. The HP heifers also had elevated $(P<0.001)$ plasma concentrations of insulin and IGF-I (Table 2). Overall, these data indicate that an elevated plane of nutrition increases systemic and mammary synthesis of leptin.

\section{Leptin Does Not Activate Intracellular Signaling in Bovine Mammary Epithelial Cells}

In other cell systems, leptin signals are transduced via 3 canonical pathways known as JAK2 (janus asso- ciated kinase 2)-STAT3, IRS (insulin receptor substrate)-PI3K (phosphoinositide 3 kinase)-AKT, and MAPK (mitogen-activated protein kinase) (Bjorbaek and Kahn, 2004; Duan et al., 2004; Myers, 2004). To assess whether the inverse relationship between leptin production and mammary parenchymal growth was causal, leptin-dependent activation of these pathways was measured in the bovine mammary epithelial cell line MAC-T. The MAC-T cells were incubated in the presence or absence of $100 \mathrm{ng} / \mathrm{mL}$ of ovine leptin for various times and cell lysates were analyzed by Western immunoblotting for the presence of phosphorylated STAT3, STAT5, AKT, or ERK1/2. Treatment with leptin did not induce phosphorylation of these proteins at any times (Figure 2; results not shown for STAT5). This failure cannot be attributed to a generalized signaling defect in MAC-T cells because target proteins were activated by other cytokines; i.e., STAT3 by IL-6, AKT by IGF-I, and ERK1/2 by TGF $\alpha$ (Figure 2 ; results not shown for STAT5 activation by IFN $\gamma$ ).

These results could reflect loss of leptin responsiveness during derivation and continuous passage of MAC-T cells. To rule out this possibility, similar signaling studies were performed in pMEC cells. As was the case for MAC-T cells, leptin did not induce phosphorylation of STAT3, STAT5, AKT, or ERK1/2 even though other cytokines readily did (Figure 3; results not shown for STAT5 activation by IL-6). In conclusion, leptin does not activate STAT3, STAT5, AKT, or ERK1/2 in bovine mammary epithelial cells.

\section{Leptin Does Not Induce Longer Term Responses in Bovine Mammary Epithelial Cells}

Absence of leptin-dependent signaling events is inconsistent with a direct action of leptin on mammary 


\section{A) STAT3}

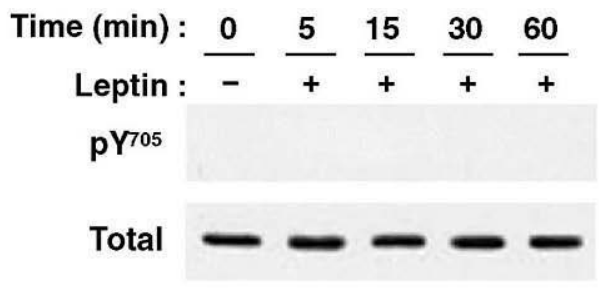

\section{A) STAT3}

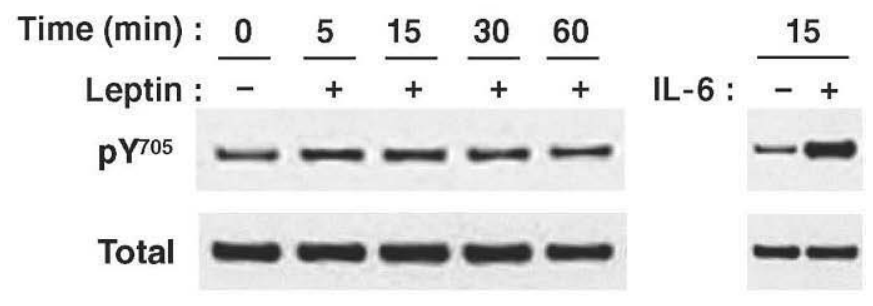

\section{B) AKT}
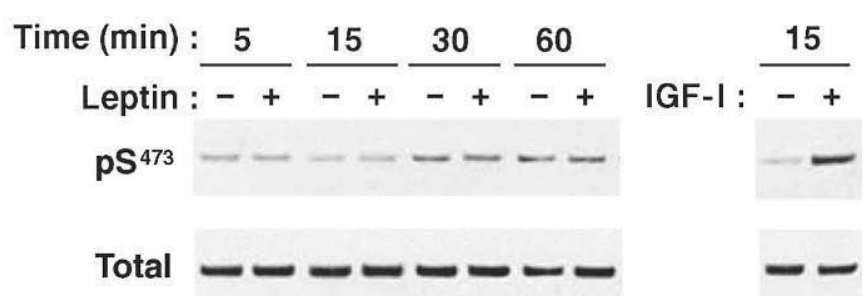

\section{C) ERK1/2}

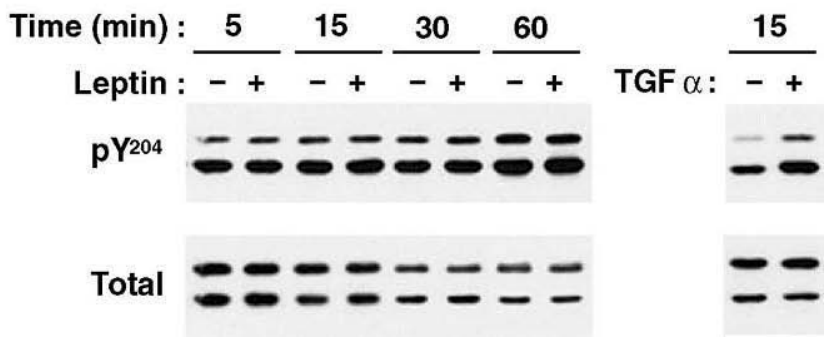

Figure 2. Effect of leptin on signal transducers and activators of transcription 3 (STAT3), Akt/Protein kinase B (AKT), and extracellular signal-regulated kinase (ERK1/2) phosphorylation in MAC-T cells. The MAC-T cells were maintained for $30 \mathrm{~h}$ in serum and insulinfree basal Dulbecco's modified Eagle's medium. Then, the cells were incubated in duplicate in the absence $(-)$ or presence $(+)$ of ovine leptin (100 ng/mL), IL-6 (50 ng/mL), IGF-I (100 ng/mL), or transforming growth factor- $\alpha$ (TGF $\alpha ; 100 \mathrm{ng} / \mathrm{mL})$. Cells were lysed at the indicated times relative to hormonal treatments. Protein lysates (20 $\mu \mathrm{g}$ ) were analyzed by Western immunoblotting for the abundance of A) tyrosine phosphorylated and total STAT3 (pY 705 and Total), B) serine phosphorylated and total AKT ( $\mathrm{pS}^{473}$ and Total), and C) tyrosine phosphorylated and total ERK1/2 ( $\mathrm{pY}^{204}$ and Total). Phosphorylated AKT and ERK1/2 varied during the time course of the experiment necessitating untreated cells at each time point. Data are representative of 2 independent experiments with ovine leptin and 4 experiments with human leptin.

epithelial cells. Alternatively, leptin could signal via an uncharacterized pathway. This possibility was assessed by evaluating the effect of leptin on previously described leptin-dependent functional responses in mammary epithelial cells. Leptin has been shown to stimulate SOCS3 mRNA expression in other leptinresponsive cells (Tsumanuma et al., 2000; Bjorbaek

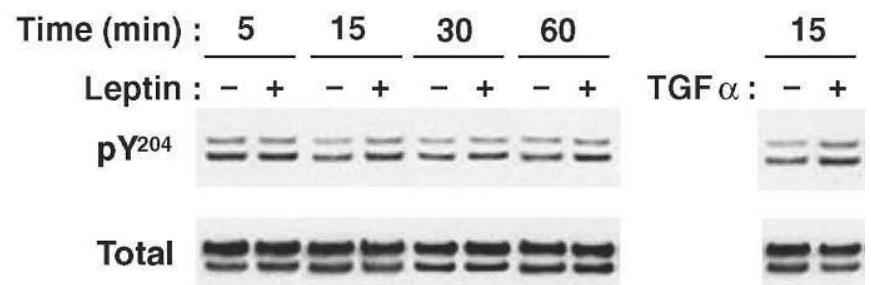

Figure 3. Effect of leptin on signal transducers and activators of transcription (STAT3), Akt/Protein kinase B (AKT), and total extracellular signal-regulated kinase (ERK1/2) phosphorylation in primary mammary epithelial cells (pMEC). The pMEC obtained from 2 separate isolations were maintained for $4 \mathrm{~h}$ in serum and insulinfree basal M199 media. Then each pMEC isolate was incubated in the absence (-) or presence (+) of ovine leptin (100 ng/mL), IL-6 (50 $\mathrm{ng} / \mathrm{mL})$, IGF-I (100 ng/mL), or transforming growth factor $\alpha$ (TGF $\alpha$; $100 \mathrm{ng} / \mathrm{mL}$ ). Cells were lysed at the indicated times relative to hormonal treatments. Protein lysates $(20 \mu \mathrm{g})$ were analyzed by Western immunoblotting for the abundance of A) tyrosine phosphorylated and total STAT3 ( $\mathrm{pY}^{705}$ and Total); B) serine phosphorylated and total AKT ( $\mathrm{pS}^{473}$ and Total); and C) tyrosine phosphorylated and total ERK1/2 (pY $\mathrm{p}^{204}$ and Total). Phosphorylated AKT and ERK1/2 varied during the time course of the experiment necessitating untreated periments.

and Kahn, 2004; Perez et al., 2004). This response was evaluated in MAC-T cells. As shown in Figure 4A, IL6 increased SOCS3 mRNA abundance within $1 \mathrm{~h}$, but leptin was completely ineffective even after $9 \mathrm{~h}$ of treatment. Next, it was determined whether leptin could attenuate IGF-I mediated proliferation as recently reported (Silva et al., 2002). The MAC-T and cells at each time point. Data are representative of 2 independent ex- 
A)

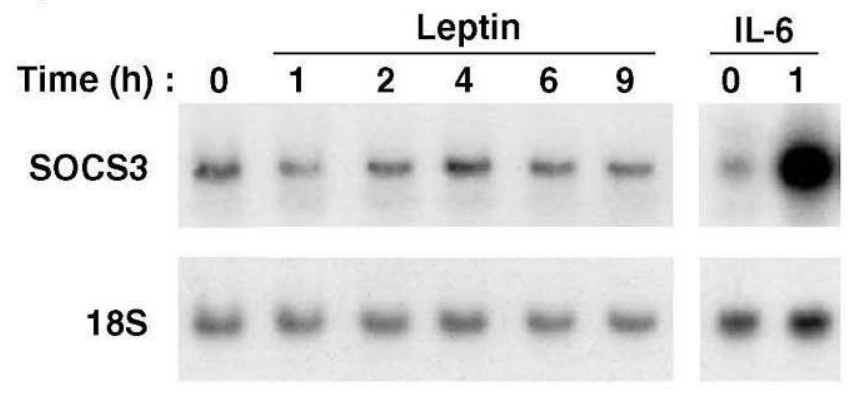

B) MAC-T

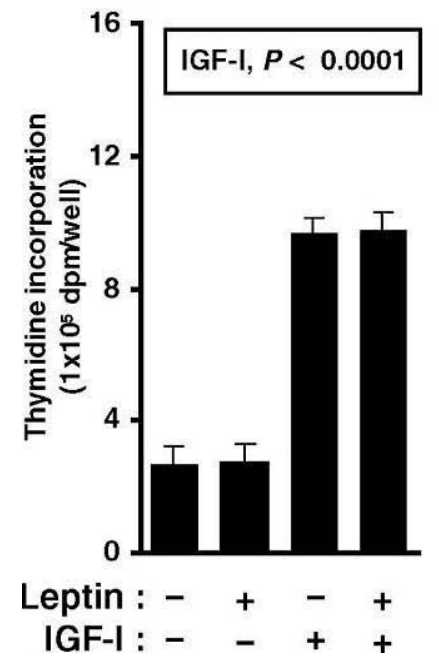

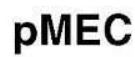

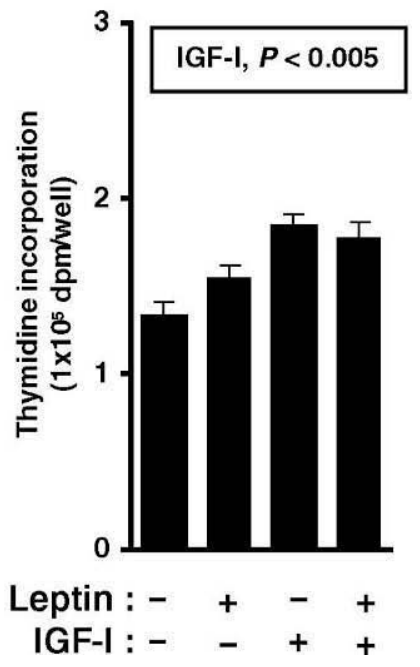

Figure 4. Effect of leptin on suppressors of cytokine signaling 3 (SOCS3) mRNA expression and $\left[{ }^{3} \mathrm{H}\right]$ thymidine incorporation in bovine mammary epithelial cells. A) The MAC-T cells were maintained for $48 \mathrm{~h}$ in serum and insulin-free basal Dulbecco's modified Eagle's medium (DMEM). Cells were then incubated in the absence or presence of leptin $(100 \mathrm{ng} / \mathrm{mL})$ or IL-6 $(30 \mathrm{ng} / \mathrm{mL})$. Total RNA was obtained at the indicated times and analyzed by Northern blotting for SOCS3 and $18 \mathrm{~S}$ ribosomal RNA abundance. B) MAC-T cells were incubated in serum and insulin-free basal DMEM for $24 \mathrm{~h}$. The primary mammary epithelial cells (pMEC) were incubated in basal M199 media supplemented with insulin for $24 \mathrm{~h}$. Cells were incubated with the same conditions in the absence or presence of ovine leptin $(100 \mathrm{ng} / \mathrm{mL})$ and IGF-I $(10 \mathrm{ng} / \mathrm{mL})$. For MAC-T cells, hormone treatments and $\left[{ }^{3} \mathrm{H}\right]$ thymidine were added for $18 \mathrm{~h}$. The pMEC cells were incubated with hormonal treatments for $4 \mathrm{~d}$ with a media change every $2 \mathrm{~d}$, and $\left[{ }^{3} \mathrm{H}\right]$ thymidine was added for the last $24 \mathrm{~h}$ of the culture period. Means \pm SEM are shown for each treatment. Significance of the IGF-I effect is indicated. Data are representative of 3 experiments for MAC-T cells and 1 experiment for the pMEC cells. Similar results were obtained in experiments performed with human leptin in MAC-T (3 experiments) and pMEC (1 experiment).

pMEC were incubated in the absence or presence of leptin, IGF-I, or their combination. Synthesis of DNA was measured by incorporation of $\left[{ }^{3} \mathrm{H}\right]$ thymidine. Synthesis of DNA was stimulated by IGF-I in both cell

systems, but leptin was devoid of significant effects in the absence or presence of IGF-I (Figure 4B). Similar data were obtained in both cell systems using $100 \mathrm{ng} /$ $\mathrm{mL}$ of human leptin (data not shown).

\section{Leptin Receptor Expression in Epithelial Cells and Tissues Derived from the Mammary Gland}

Based on these findings, we hypothesized that leptin receptor abundance is the factor limiting leptin-dependent responses in mammary epithelial cells. Multiple leptin receptor isoforms have been described, but only the full length $\mathrm{Ob}-\mathrm{Rb}$ and the truncated Ob-Ra isoforms have been shown to signal in vitro (Bjorbaek et al., 1997; Ahima and Flier, 2000). Isoform-specific, real-time PCR assays were used to evaluate $\mathrm{Ob}-\mathrm{Rb}$ and Ob-Ra mRNA abundance in mammary epithelial cells (Table 1). The Ob-Rb and Ob-Ra mRNA transcripts were detected in the hypothalamus, but not in MAC-T and pMEC cells. A third real-time PCR assay measuring mRNA encoding all leptin receptor isoforms $\left(O b-R_{\text {Total }}\right)$ also failed to yield signals in MAC$\mathrm{T}$ and pMEC cells. Total leptin receptor expression in bovine mammary epithelial cells, based on the detection limit of this last assay, was calculated to be less than $0.8 \%$ of hypothalamic expression.

Leptin receptor expression was also evaluated in the mammary tissue compartments of NP and HP heifers. The Ob- $\mathrm{R}_{\text {Total }}$ and Ob-Ra expression was greater $(P<$ 0.001 ) in the stromal than parenchymal compartment, but their expression was not affected by the plane of nutrition (Figure 5). In contrast, expression of the fully competent $\mathrm{Ob}-\mathrm{Rb}$ isoform was not detected in either tissue. These data show that both tissue compartments of the mammary gland express Ob-Ra and perhaps other short leptin receptor isoforms, but rule out epithelial cells as a major source of leptin receptor expression.

\section{DISCUSSION}

At least 2 conditions must be satisfied for leptin to directly mediate the inhibitory effect of nutrition on mammary parenchymal growth. First, as shown in this work, leptin production must be increased in heifers with decreased mammary parenchymal growth. Our group and others had previously reported positive relationships between nutrition and plasma leptin in ruminants at other physiological states (Chilliard et al., 2005; Boisclair et al., 2006). It was not immediately obvious that nutrition would exert a positive effect on plasma leptin in dairy heifers because they maintain low and nearly constant plasma leptin until puberty (Block et al., 2003). More relevant to mammary devel- 


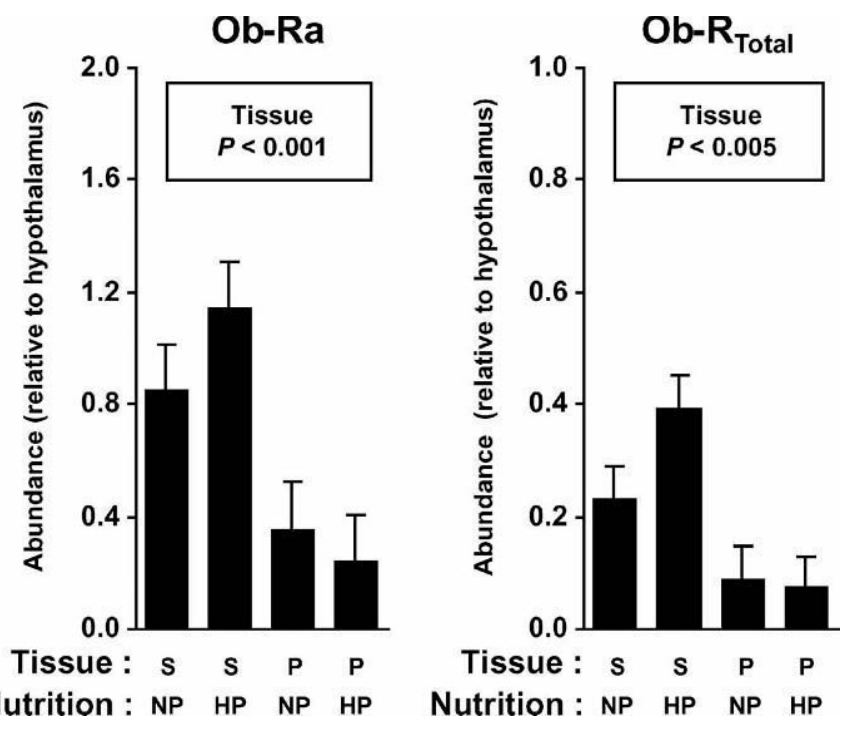

Figure 5. Effect of nutrition and mammary tissue compartments on leptin receptor (Ob-R) expression. Dairy heifers were offered a normal (NP) or high (HP) plane of nutrition between $42 \mathrm{~d}$ of age and slaughter at $240 \mathrm{~kg}$. Mammary stroma (S) and parenchyma (P) were obtained at slaughter. Total RNA was extracted from stromal or parenchymal tissue and assayed for the abundance of $\mathrm{Ob}-\mathrm{Ra}$ and $\mathrm{Ob}$ $\mathrm{R}_{\text {Total }}$ mRNA using real-time PCR (8 heifers per treatment). For both transcripts, expression is expressed relative to a hypothalamic RNA pool. Means \pm SEM are shown for each treatment and the significant effect of tissue (stroma vs. parenchyma) is reported.

opment, our data demonstrate that leptin production increased in the mammary stroma, in close proximity with the developing epithelium. These data are physiologically consistent with leptin mediating the effects of nutrition on mammary epithelial cells. Leptin expression was lesser in the parenchyma. This expression is likely accounted for by adipose tissue infiltrating the parenchyma because leptin mRNA could not be detected in the pMEC cells. Absence of expression in the pMEC cells contrasts with the small, but detectable, expression in epithelial cells isolated from differentiated mammary glands (Smith-Kirwin et al., 1998; Aoki et al., 1999; Leury et al., 2003).

A second condition necessary for the role of leptin is the presence of the functional receptor in mammary tissue and epithelial cells. Transcription of the single leptin receptor gene gives rise to many alternatively spliced mRNA transcripts that encode specific membrane-bound isoforms (Ahima and Flier, 2000). In rodents and humans, these include the full-length form of the receptor $(\mathrm{Ob}-\mathrm{Rb})$ and many truncated isoforms lacking most of the cytoplasmic domain (Ob-Ra, ObRc, Ob-Rd, and Ob-Rf; Ahima and Flier, 2000). The full complement of leptin receptor transcripts has not been described in cattle, but $\mathrm{Ob}-\mathrm{Rb}$ and $\mathrm{Ob}-\mathrm{Ra}$ are present (Silva et al., 2002; Chelikani et al., 2003). As shown herein, the assay detecting all receptor isoforms yielded greater expression in the stroma than parenchyma. The Ob-Ra transcripts followed a similar spatial distribution. More significantly, however, the abundance of Ob-Rb transcripts in either tissue was negligible relative to that in the hypothalamus, the predominant leptin target tissue (Ahima and Flier, 2000; Bjorbaek and Kahn, 2004; Myers, 2004). Our findings are in agreement with data indicating that short leptin receptor isoforms predominate in the ovine mammary gland (Laud et al., 1999), but differ from nonquantitative reverse transcription-PCR data in cattle showing ubiquitous $\mathrm{Ob}-\mathrm{Rb}$ expression, including in the mammary parenchymal and stromal tissue of heifers and dry and lactating cows (Silva et al., 2002; Chelikani et al., 2003; Sayed-Ahmed et al., 2004). Our quantitative results reported here indicate that mammary expression of Ob-Rb is very low in prepubertal dairy heifers. Previous detection of Ob-Rb in the mammary gland likely reflects the ability of RT-PCR to amplify extremely small amounts of mRNA. Of note, exclusion of the 2 pubertal HP heifers in this study did not alter our findings on mammary gland growth, leptin, or leptin receptor expression (results not shown).

The Ob-Rb form activates all signal transduction pathways attributed to leptin including JAK2-STAT3, IRS-PI3K-AKT, and MAPK (Bjorbaek and Kahn, 2004; Duan et al., 2004; Myers, 2004), whereas Ob-Ra activity is weak and limited to the IRS and MAPK pathways (Bjorbaek et al., 1997; Myers, 2004). These signaling events occur within minutes of leptin binding, and thus, correspond to the earliest detectable responses. Leptin-dependent activation of any of these pathways was not detected in MAC-T cells; similarly, leptin did not affect SOCS3 mRNA expression or cell proliferation. This last observation agrees with the recently reported absence of leptin effects on MAC-T cell proliferation under basal conditions, but is at odds with its reported ability to attenuate IGF-I-stimulated proliferation (Silva et al., 2002).

The inability to detect responses to ovine and human leptin used in our studies does not reflect poor bioactivity, because both produced robust increases in luciferase activity in HEK 293 cells transfected with plasmids encoding bovine $\mathrm{Ob}-\mathrm{Rb}$ and a STAT3-dependent luciferase vector (S. Thorn and Y. Boisclair, unpublished data). Rather, it relates to the negligible expression of any leptin receptor isoform in MAC-T cells under the conditions used in our studies. Previous leptin experiments in MAC-T cells were performed in the presence of insulin $(1 \mathrm{ng} / \mathrm{mL})$, and effects of leptin were detected only after prolonged coincubation with IGFI (Silva et al., 2002). With this in mind, the possibility 
that chronic insulin or IGF-I treatments were needed for leptin receptor expression was considered. Experiments were performed in which MAC-T were pretreated for $24 \mathrm{~h}$ with $100 \mathrm{ng} / \mathrm{mL}$ of IGF-I or $1 \mathrm{ng} / \mathrm{mL}$ of insulin, and then stimulated with leptin for 5, 15, 30 , or $60 \mathrm{~min}$. In other experiments, signaling was evaluated after 3 or $24 \mathrm{~h}$ of coincubation with leptin and either IGF-I or insulin. These conditions did not lead to detectable receptor expression, leptin-dependent signaling, or proliferation responses (results not shown).

To extend the physiological significance of the MAC$T$ results, the signaling and proliferation experiments were repeated in pMEC isolated from prepubertal dairy heifers. These cells proliferated in response to IGF-I and display cytokine-dependent induction of STAT3, STAT5, AKT, and ERK1/2. As was the case for MAC-T cells, leptin-dependent responses were not detected, again presumably because of negligible leptin receptor expression. This last finding indicates that parenchymal receptor expression is restricted to nonepithelial cell populations (i.e., fibroblasts and adipocytes). Irrespective of the explanation for the failure to observe leptin responses in MAC-T cells, our results with the primary cells indicate that leptin does not act directly on mammary epithelial cells in prepubertal dairy heifers.

Recent preliminary results show that intramammary administration of leptin reduced basal and IGFI-mediated bromodeoxyuridine incorporation in mammary epithelial cells of prepubertal heifers (Silva et al., 2003). The absence of the leptin receptor in pMEC suggests 2 possible explanations for these results. First, it may be that injection of recombinant leptin elicited a local inflammatory response. This reaction has been encountered by others using recombinantly derived IGF-I and bST even though the material used was devoid of measurable endotoxins (Mackle et al., 2000). Second, it is also possible that leptin acted on immune cells residing in the mammary gland and stimulated secretion of cytokines capable of inhibiting IGF-I-mediated actions. Indeed, leptin has been shown to stimulate the release of IL-1, IL-6, and tumor necrosis factor-alpha from monocytes and macrophages (Lord et al., 1998; Sanchez-Margalet et al., 2003; La Cava and Matarese, 2004; Matarese et al., 2005) and these inflammatory cytokines are potent inhibitors of IGF-I-stimulated proliferation in a variety of cell types (Shen et al., 2002, 2004; Strle et al., 2004).

\section{CONCLUSIONS}

In summary, increased circulating and mammary synthesis of leptin were measured in heifers fed a high plane of nutrition. Bovine mammary epithelial cells, however, had negligible leptin receptor expression and did not respond to leptin in vitro. Therefore, leptin cannot mediate the effects of nutrition by acting directly on mammary epithelial cells. The possibility that leptin has an impact on mammogenesis by altering the production of cytokines from other cell populations remains to be explored.

\section{ACKNOWLEDGMENTS}

The authors thank R. M. Ehrhardt for performing the leptin hormone assay, A. Kamgaard Nielsen and H. Møller Purup for assisting with pMEC cells and insulin and IGF-I hormone assays, and J. W. Kim for assisting with the leptin ribonuclease protection assay. This work was supported by the USDA National Research Initiative Competitive Grant Program (Award 00-35206-9352 to Y. R. Boisclair) and by the Cornell University Agricultural Experiment Station.

\section{REFERENCES}

Ahima, R. S., and J. S. Flier. 2000. Leptin. Annu. Rev. Physiol. 62:413-437.

Akers, R. M., T. B. McFadden, S. Purup, M. Vestergaard, K. Sejrsen, and A. V. Capuco. 2000. Local IGF-I axis in peripubertal ruminant mammary development. J. Mammary Gland Biol. Neoplasia 5:43-51.

Aoki, N., M. Kawamura, and T. Matsuda. 1999. Lactation-dependent down regulation of leptin production in mouse mammary gland. Biochim. Biophys. Acta 1427:298-306.

Berry, S. D., T. B. McFadden, R. E. Pearson, and R. M. Akers. 2001. A local increase in the mammary IGF-1:IGFBP-3 ratio mediates the mammogenic effects of estrogen and growth hormone. Domest. Anim. Endocrinol. 21:39-53.

Bjorbaek, C., and B. B. Kahn. 2004. Leptin signaling in the central nervous system and the periphery. Recent Prog. Horm. Res. 59:305-331.

Bjorbaek, C., S. Uotani, B. da Silva, and J. S. Flier. 1997. Divergent signaling capacities of the long and short isoforms of the leptin receptor. J. Biol. Chem. 272:32686-32695.

Block, S. S., W. R. Butler, R. A. Ehrhardt, A. W. Bell, M. E. Van Amburgh, and Y. R. Boisclair. 2001. Decreased concentration of plasma leptin in periparturient dairy cows is caused by negative energy balance. J. Endocrinol. 171:339-348.

Block, S. S., J. M. Smith, R. A. Ehrhardt, M. C. Diaz, R. P. Rhoads, M. E. Van Amburgh, and Y. R. Boisclair. 2003. Nutritional and developmental regulation of plasma leptin in dairy cattle. J. Dairy Sci. 86:3206-3214.

Boisclair, Y. R., S. R. Wesolowski, J. W. Kim, and R. A. Ehrhardt. 2006. Roles of growth hormone and leptin in the periparturient dairy cow. Pages 327-346 in Proc. Xth Int. Symp. Ruminant Physiol. K. Sejrsen, T. Hvelplund, and M. O. Nielsen, ed. Wageningen Acad. Publ., Wageningen, The Netherlands.

Bustin, S. A., and T. Nolan. 2004. Pitfalls of quantitative real-time reverse-transcription polymerase chain reaction. J. Biomol. Tech. 15:155-166.

Capuco, A. V., J. J. Smith, D. R. Waldo, and C. E. Rexroad, Jr. 1995. Influence of prepubertal dietary regimen on mammary growth of Holstein heifers. J. Dairy Sci. 78:2709-2725. 
Chelikani, P. K., D. R. Glimm, and J. J. Kennelly. 2003. Short communication: Tissue distribution of leptin and leptin receptor mRNA in the bovine. J. Dairy Sci. 86:2369-2372.

Chilliard, Y., C. Delavaud, and M. Bonnet. 2005. Leptin expression in ruminants: Nutritional and physiological regulations in relation with energy metabolism. Domest. Anim. Endocrinol. 29:3-22.

Chomczynski, P., and N. Sacchi. 1987. Single-step method of RNA isolation by acid guanidinium thiocyanate-phenol-chloroform extraction. Anal. Biochem. 162:156-159.

Couldrey, C., J. Moitra, C. Vinson, M. Anver, K. Nagashima, and J. Green. 2002. Adipose tissue: A vital in vivo role in mammary gland development but not differentiation. Dev. Dyn. 223:459-468.

Deindl, E. 2001. 18S ribosomal RNA detection on Northern blot employing a specific oligonucleotide. Biotechniques 31:1250, 1252.

Duan, C., M. Li, and L. Rui. 2004. SH2-B promotes insulin receptor substrate 1 (IRS1)- and IRS2-mediated activation of the phosphatidylinositol 3-kinase pathway in response to leptin. J. Biol. Chem. 279:43684-43691.

Ehrhardt, R. A., R. M. Slepetis, J. Siegal-Willott, M. E. Van Amburgh, A. W. Bell, and Y. R. Boisclair. 2000. Development of a specific radioimmunoassay to measure physiological changes of circulating leptin in cattle and sheep. J. Endocrinol. 166:519528.

Frystyk, J., B. Dinesen, and H. Orskov. 1995. Non-competitive timeresolved immunofluorometric assays for determination of human insulin-like growth factor I and II. Growth Regul. 5:169176.

Grill, C. J., and W. S. Cohick. 2000. Insulin-like growth factor binding protein-3 mediates IGF-I action in a bovine mammary epithelial cell line independent of an IGF interaction. J. Cell. Physiol. 183:273-283.

Hovey, R. C., T. B. McFadden, and R. M. Akers. 1999. Regulation of mammary gland growth and morphogenesis by the mammary fat pad: A species comparison. J. Mammary Gland Biol. Neoplasia 4:53-68.

Huynh, H. T., G. Robitaille, and J. D. Turner. 1991. Establishment of bovine mammary epithelial cells (MAC-T): An in vitro model for bovine lactation. Exp. Cell Res. 197:191-199.

Kleinberg, D. L., M. Feldman, and W. Ruan. 2000. IGF-I: An essential factor in terminal end bud formation and ductal morphogenesis. J. Mammary Gland Biol. Neoplasia 5:7-17.

La Cava, A., and G. Matarese. 2004. The weight of leptin in immunity. Nat. Rev. Immunol. 4:371-379.

Laud, K., I. Gourdou, L. Belair, D. H. Keisler, and J. Djiane. 1999. Detection and regulation of leptin receptor mRNA in ovine mammary epithelial cells during pregnancy and lactation. FEBS Lett. 463:194-198.

Leury, B. J., L. H. Baumgard, S. S. Block, N. Segoale, R. A. Ehrhardt, R. P. Rhoads, D. E. Bauman, A. W. Bell, and Y. R. Boisclair. 2003. Effect of insulin and growth hormone on plasma leptin in periparturient dairy cows. Am. J. Physiol. Regul. Integr. Comp. Physiol. 285:R1107-R1115.

Lord, G. M., G. Matarese, J. K. Howard, R. J. Baker, S. R. Bloom, and R. I. Lechler. 1998. Leptin modulates the T-cell immune response and reverses starvation-induced immunosuppression. Nature 394:897-901.

Lovendahl, P., and H. M. Purup. 2002. Technical note: Time-resolved fluoro-immunometric assay for intact insulin in livestock species. J. Anim. Sci. 80:191-195.

Mackle, T. R., D. A. Dwyer, and D. E. Bauman. 2000. Intramammary infusion of insulin or long R3 insulin-like growth factor-I did not increase milk protein yield in dairy cows. J. Dairy Sci. 83:1740-1749.

Matarese, G., S. Moschos, and C. S. Mantzoros. 2005. Leptin in immunology. J. Immunol. 174:3137-3142.
Myers, M. G., Jr. 2004. Leptin receptor signaling and the regulation of mammalian physiology. Recent Prog. Horm. Res. 59:287-304.

Perez, C., C. Fernandez-Galaz, T. Fernandez-Agullo, C. Arribas, A. Andres, M. Ros, and J. M. Carrascosa. 2004. Leptin impairs insulin signaling in rat adipocytes. Diabetes 53:347-353.

Purup, S., S. K. Jensen, and K. Sejrsen. 2001. Differential effects of retinoids on proliferation of bovine mammary epithelial cells in collagen gel culture. J. Dairy Res. 68:157-164.

Purup, S., K. Sejrsen, J. Foldager, and R. M. Akers. 1993. Effect of exogenous bovine growth hormone and ovariectomy on prepubertal mammary growth, serum hormones and acute in-vitro proliferative response of mammary explants from Holstein heifers. J. Endocrinol. 139:19-26.

Purup, S., M. Vestergaard, and K. Sejrsen. 2000a. Involvement of growth factors in the regulation of pubertal mammary growth in cattle. Adv. Exp. Med. Biol. 480:27-43.

Purup, S., M. Vestergaard, M. S. Weber, K. Plaut, R. M. Akers, and K. Sejrsen. 2000b. Local regulation of pubertal mammary growth in heifers. J. Anim. Sci. 78(Suppl. 3):36-47.

Radcliff, R. P., M. J. VandeHaar, A. L. Skidmore, L. T. Chapin, B. R. Radke, J. W. Lloyd, E. P. Stanisiewski, and H. A. Tucker. 1997. Effects of diet and bovine somatotropin on heifer growth and mammary development. J. Dairy Sci. 80:1996-2003.

Richards, R. G., D. M. Klotz, M. P. Walker, and R. P. Diaugustine. 2004. Mammary gland branching morphogenesis is diminished in mice with a deficiency of insulin-like growth factor-I (IGF-I), but not in mice with a liver-specific deletion of IGF-I. Endocrinology 145:3106-3110.

Sanchez-Margalet, V., C. Martin-Romero, J. Santos-Alvarez, R. Goberna, S. Najib, and C. Gonzalez-Yanes. 2003. Role of leptin as an immunomodulator of blood mononuclear cells: Mechanisms of action. Clin. Exp. Immunol. 133:11-19.

Sayed-Ahmed, A., M. Kulcsar, P. Rudas, and T. Bartha. 2004. Expression and localisation of leptin and leptin receptor in the mammary gland of the dry and lactating non-pregnant cow. Acta Vet. Hung. 52:97-111.

Sejrsen, K., J. Foldager, M. T. Sorensen, R. M. Akers, and D. E. Bauman. 1986. Effect of exogenous bovine somatotropin on pubertal mammary development in heifers. J. Dairy Sci. 69:1528-1535.

Sejrsen, K., J. T. Huber, H. A. Tucker, and R. M. Akers. 1982. Influence of nutrition of mammary development in pre- and postpubertal heifers. J. Dairy Sci. 65:793-800.

Sejrsen, K., S. Purup, M. Vestergaard, and J. Foldager. 2000. High body weight gain and reduced bovine mammary growth: Physiological basis and implications for milk yield potential. Domest. Anim. Endocrinol. 19:93-104.

Sejrsen, K., S. Purup, M. Vestergaard, M. S. Weber, and C. H. Knight. 1999. Growth hormone and mammary development. Domest. Anim. Endocrinol. 17:117-129.

Shen, W. H., J. H. Zhou, S. R. Broussard, G. G. Freund, R. Dantzer, and K. W. Kelley. 2002. Proinflammatory cytokines block growth of breast cancer cells by impairing signals from a growth factor receptor. Cancer Res. 62:4746-4756.

Shen, W. H., J. H. Zhou, S. R. Broussard, R. W. Johnson, R. Dantzer, and K. W. Kelley. 2004. Tumor necrosis factor alpha inhibits insulin-like growth factor I-induced hematopoietic cell survival and proliferation. Endocrinology 145:3101-3105.

Silva, L. F. P., J. S. Liesman, M. S. Weber Nielsen, and M. J. VandeHaar. 2003. Intramammary infusion of leptin decreases proliferation of mammary epithelial cells in prepubertal heifers. J. Dairy Sci. 86(Suppl. 1):166. (Abstr.)

Silva, L. F., M. J. VandeHaar, M. S. Weber Nielsen, and G. W. Smith. 2002. Evidence for a local effect of leptin in bovine mammary gland. J. Dairy Sci. 85:3277-3286.

Smith-Kirwin, S. M., D. M. O'Connor, J. De Johnston, E. D. Lancey, S. G. Hassink, and V. L. Funanage. 1998. Leptin expression in human mammary epithelial cells and breast milk. J. Clin. Endocrinol. Metab. 83:1810-1813. 
Strle, K., S. R. Broussard, R. H. McCusker, W. H. Shen, R. W. Johnson, G. G. Freund, R. Dantzer, and K. W. Kelley. 2004. Proinflammatory cytokine impairment of insulin-like growth factor I-induced protein synthesis in skeletal muscle myoblasts requires ceramide. Endocrinology 145:4592-4602.

Tsumanuma, I., L. Jin, S. Zhang, J. M. Bayliss, B. W. Scheithauer, and R. V. Lloyd. 2000. Leptin signal transduction in the HP75 human pituitary cell line. Pituitary 3:211-220.

Weber, M. S., S. Purup, M. Vestergaard, R. M. Akers, and K. Sejrsen. 2000a. Nutritional and somatotropin regulation of the mitogenic response of mammary cells to mammary tissue extracts. Domest. Anim. Endocrinol. 18:159-164.

Weber, M. S., S. Purup, M. Vestergaard, R. M. Akers, and K. Sejrsen. $2000 \mathrm{~b}$. Regulation of local synthesis of insulin-like growth factor$\mathrm{I}$ and binding proteins in mammary tissue. J. Dairy Sci. 83:30-37.

Weber, M. S., S. Purup, M. Vestergaard, S. E. Ellis, J. ScndergardAndersen, R. M. Akers, and K. Sejrsen. 1999. Contribution of insulin-like growth factor (IGF)-I and IGF-binding protein-3 to mitogenic activity in bovine mammary extracts and serum. J. Endocrinol. 161:365-373. 